\title{
How is the perception of the certified organic food benefits in a population from Estado de México region
}

\author{
Hernández-Rivera, Ana Bethsi ${ }^{1}$; Gruz Monterrosa, Rosy Gabriela ${ }^{2}$; Jiménez-Guzmán, Judith ${ }^{2}$; \\ León-Espinosa, Erika Berenice ${ }^{2}$; García-Garibay, Mariano ${ }^{2}$; Fabela-Morón, Miriam Fabela ${ }^{2}$; \\ Díaz-Ramírez, Mayra ${ }^{2}$; Rayas-Amor, Adolfo Armando ${ }^{2}$; Ruiz-Hernández, Rafael ${ }^{2}$; \\ Pérez-Ruiz, Rigoberto Vicencio ${ }^{2 *}$ \\ 1 Licenciatura en Ciencia y Tecnología de Alimentos. División de Ciencias Biológicas y dela Salud. Universidad \\ Autónoma Metropolitana, Unidad Lerma. Av. de las Garzas No. 10, Col. El Panteón, Municipio Lerma de \\ Villada, Estado de México, G.P. 52005. \\ 2 Departamento de Ciencias de la Alimentación. División de Ciencias Biológicas y de la Salud. Universidad \\ Autónoma Metropolitana Unidad Lerma. Av. de las Garzas 10. Col. El Panteón, Lerma de Villada, Estado \\ de México. C. P. 52005. \\ * Correspondence: rv.perez@correo.ler.uam.mx
}

Gitation: Hernández-Rivera, A. B. Cruz-Monterrosa, R. G., JiménezGuzmán, J., León-Espinosa, E. B., García-Garibay, M.,Fabela-Morón, M. F., Díaz-Ramírez, M., Rayas-Amor, A. A., Ruiz-Hernández, R., \& Pérez-Ruiz, R.V. (2021). How is the perception of the certified organic food benefits in a population from Estado de México region. Agro Productividad. https://doi. org/10.32854/agrop.v14i9.2141

Editor in Chief: Dr. Jorge Cadena Iñiguez

Received: March 13, 2021. Accepted: August 14, 2021.

Published on-line: October 12, 2021

This work is licensed under a

Creative Commons Attribution-NonCommercial 4.0 International license.

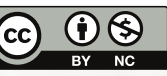

\section{ABSTRACT}

Objective: To study and understand the population's perception in a region of the Estado de Mexico about the role of certified organic food in health and the environment, as well as the economic impact generated by its consumption.

Desing/methodology/approach: A survey was conducted among a population sample of 10 municipalities in the Estado de Mexico, which consisted of seven questions related to certified organic food.

Results: The population has an idea about what certified organic food is, although they confuse it with other types of food.

Study limitations/ implications: Results were obtained from an e-mail survey because this study was conducted during the current 2020-2021 pandemic.

Findings/conclusion: The information obtained suggests that the population has a great perception about the intake of certified organic food, but there is confusion about other types of food. However, the population is willing to consume them because of their potential health and environment benefits.

\section{INTRODUCTION}

A part of the world's population is interested in producing and consuming certified organic food. However, this issue is complex to understand for several reasons, but one of the most frequent is that the concept is not properly applied, resulting in a lot of 
misinformation about these products (Gentile and Rodríguez, 2006; Cooper et al., 2007; Díaz-Víquez et al., 2015).

The term "organic" applies to products that have been produced based on a certification scheme with organic specifications throughout the production, storage, processing, handling and marketing stages (Mc Donnel-Bernabé et al., 2008; Rembiałkowska et al., 2008; Romero-Valenzuela et al., 2016). In particular for plant food, the seeds must be certified; they must be approved by a certifying authority, applying the correct sowing, harvesting and post-harvesting techniques, without the application of chemical fertilizers to the soil. Finally, the food will be labeled by adding the seal provided as "Organic Food" certified by a legal and constituted authority (FAO, 2007).

Furthermore, "organic" is about a process and not a specific product, in such a way it does not mean that organic food will provide more nutrients, proteins, or that are healthier, safer, or completely natural. Rather, it refers to an adjustment of standards that include the way of producing, storing, processing, and handling (FAO, 2007).

In Mexico, organic agriculture has a small production with low capital use, so this production system can be locally adaptable. In addition, there is a great diversity of crops due to the genetic variety, in certified organic crops the use of energy external sources for harvesting is reduced and weed control is done in a traditional way (chemicals are not used). It is also relevant to state that exists a low technological dependency and few external resources for production, however an economic risk exists in the financial investment when seeking to work as an organic farmer (Brundtland, 1987; Fließbach $e t$ al., 2007).

Mexico's Organic Food sector grew significantly from 2000 to 2010, positioning itself as a country with a high degree of organic farms registration (Willer et al., 2012). Therefore, in 2014 the government introduced the national label for organic products to certify organic food (Sello Alimento Orgánico-SAGARPA; SAGARPA, 2016). It is essential to highlight the impact of seals on the certification for organic food produced in Mexico, since a controversy exists between a "natural" food (a product that is harvested at home or in the field) which is currently confused as "organic" food. It is therefore indispensable to identify a certified organic food, which assures the potential health benefits that can provide by being free of toxic residues from chemical compounds that are often used in harvesting and post-harvesting (Kenneth and Bugusu, 2007; Camacho et al., 2001; Gobierno de México, 2018).

On the other hand, consumers consider several factors when purchasing conventional products, such as price, availability, nutritional contribution to health, and so on (Gómez et al., 1999; Gómez et al., 2002).

Therefore, the development of a wide, inclusive, and efficient supply and distribution system for this type of products, as well as the management of adequate information, are needed to encourage the consumers' interest in these products.

Since the broad market for certified organic products has a great potential for development, the aim of this study was to analyze the link between the economy, health and the environment according to the knowledge about the use of certified organic foods in a population sample in a particular region of the Estado de Mexico. 


\section{MATERIALS AND METHODS}

Sample size: To find out the population's opinion about certified organic food, a public opinion survey was randomly applied to 83 people from 10 municipalities in the Estado de Mexico (Toluca de Lerdo, San Mateo Atenco, Metepec, Lerma de Villada, Ocoyoacac, Jilotepec, Temoaya, Jiquipilco, Ecatepec de Morelos and Tejupilco).

Application: A survey was conducted via e-mail, mainly because this study was carried out during the pandemic season due to the recent worldwide affectation by the severe respiratory syndrome coronavirus 2 (SARS-CoV-2), therefore it was decided to apply multiple-choice questions. The questionnaire was composed by 7 questions aimed to know: a) consumption, b) purchasing establishments, c) monetary value, d) health benefits and e) environmental impact of certified organic food. At the beginning of the survey, the following description of certified organic product was placed: The term organic applies to products that were produced based on Organic Standards throughout the production, handling, processing and marketing phase (excluding the use of chemical fertilizers) and which has been approved by a certifying authority. Organic refers to a process rather than a product (Food and Agriculture Organization of the United Nations, 2007).

In the Google Forms survey, the participants' name, gender and age was requested, and the questions were: 1) Has your perspective of organic food concept changed based on the above definition? 2) Have you ever consumed certified organic food? 3) Do you know any establishment or online store where certified organic food can be purchased? 4) Which is that establishment or online store? 5) Do you think that the price of certified organic food is more expensive, so it probably impacts your consumption choice? 6) Do you consider that eating certified organic food is beneficial or detrimental to your health? 7) Do you consider that certified organic foods impact positively or negatively on the environment? Automatic graphs were generated with the collected results. Afterwards, the data was tabulated in Microsoft Excel/Windows 10 to visualize the responses of each participant (Table 1).

\section{RESULTS AND DISGUSSION}

The study was conducted to determine the perception that the population has of certified organic foods and the existing association between factors that are decisive for their consumption, such as their price and the potential benefits that can have an impact on the health of the consumer and the environment. As a first step, the information was processed to obtain, on the one hand, a record of the sexes and, on the other, a record of the ages. It was found that $39 \%$ of the people were female, $59.8 \%$ were male and $1.2 \%$ of the population did not want to answer what sex they were (Figure 1). Interestingly, we would expect more women to answer the survey, but the percentage of men who answered it was higher, suggesting that even though women traditionally decide on the acquisition of food for household consumption in Mexico, it seems that a high percentage of men were interested in this topic and had an opinion about it.

The age range is from 18 years old to 53 years old (Figure 2). Which represents a broad sector of the population that may have the possibility to choose to buy food. 
Table 1. Response options for each of the questions asked

\begin{tabular}{|c|c|}
\hline Questions & Answer options \\
\hline $\begin{array}{l}\text { 1) Has your perspective of organic food concept } \\
\text { changed based on the above definition? }\end{array}$ & $\begin{array}{l}\text { a) Yes } \\
\text { b) No }\end{array}$ \\
\hline 2) Have your ever consumed certified organic food? & $\begin{array}{l}\text { a) Yes } \\
\text { b) No } \\
\text { c) Maybe }\end{array}$ \\
\hline $\begin{array}{l}\text { 3) Do you know any establishment or online store } \\
\text { where certified organic food can be purchased? }\end{array}$ & $\begin{array}{l}\text { a) Yes } \\
\text { b) No }\end{array}$ \\
\hline 4) Which is that establishment or online store? & $\begin{array}{l}\text { a) I don't know about any establishment } \\
\text { b) Local markets } \\
\text { c) Supermarket } \\
\text { d) Internet (Amazon, Mercado libre, etc.) } \\
\text { e) Other }\end{array}$ \\
\hline $\begin{array}{l}\text { 5) Do you think that the price of certified organic } \\
\text { food is more expensive, so it probably impacts } \\
\text { your consumption choice? }\end{array}$ & $\begin{array}{l}\text { a) Yes } \\
\text { b) No } \\
\text { c) Maybe }\end{array}$ \\
\hline $\begin{array}{l}\text { 6) Do you consider that eating certified organic } \\
\text { food is beneficial or detrimental to you health? }\end{array}$ & $\begin{array}{l}\text { a) It is health.promoting } \\
\text { b) It isn't health-promoting } \\
\text { c) It promotes or harms health according to the frequency with which it is consumed }\end{array}$ \\
\hline $\begin{array}{l}\text { 7) Do you consider that certified organic foods } \\
\text { impact positively or negatively on the } \\
\text { environment }\end{array}$ & $\begin{array}{l}\text { a) Positive for the environment } \\
\text { b) Negative for the environment } \\
\text { c) I am unaware of the impact that certified organic products have on the environmental }\end{array}$ \\
\hline
\end{tabular}

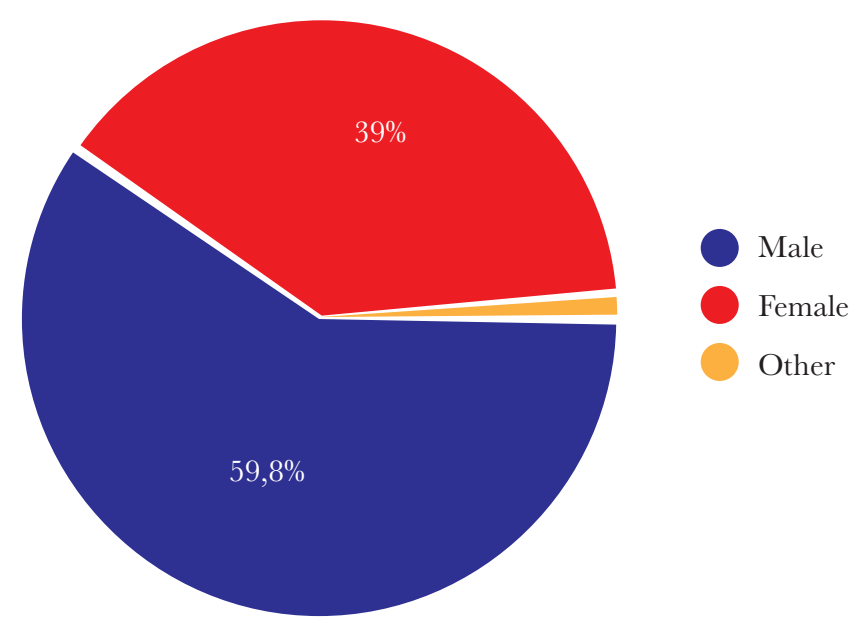

Figure 1. Percentage representation of registered sexes.

According to FAO's definition of organic food incorporated in the survey, it was asked if the perspective of the concept of organic food had changed. It was found that $60.2 \%$ of the interviewed population had changed their point of view, demonstrating that the main problem was to define organic food with other kinds of it. However, the remaining $39.8 \%$ of the interviewed population (Figure 3) kept the term organic food as simply grown at home, regardless of whether pesticides, pesticides, and chemical fertilizers are used, whether the seeds they use are certified or not, or even if the soil conditions and cultivation techniques are the ideal ones. 


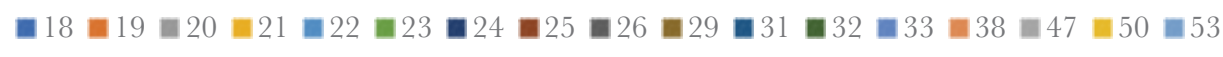

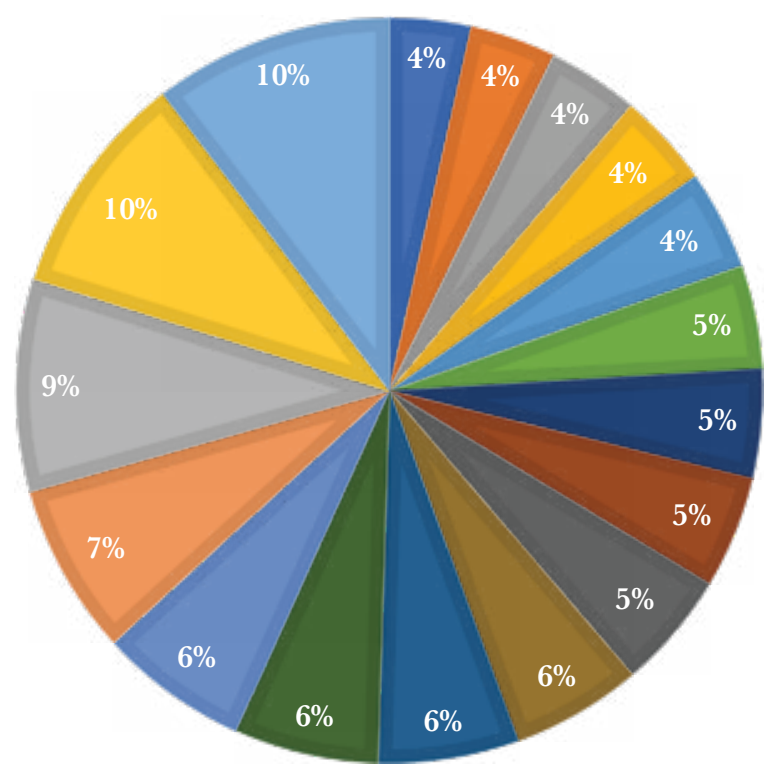

Figure 2. Age register of the participants.

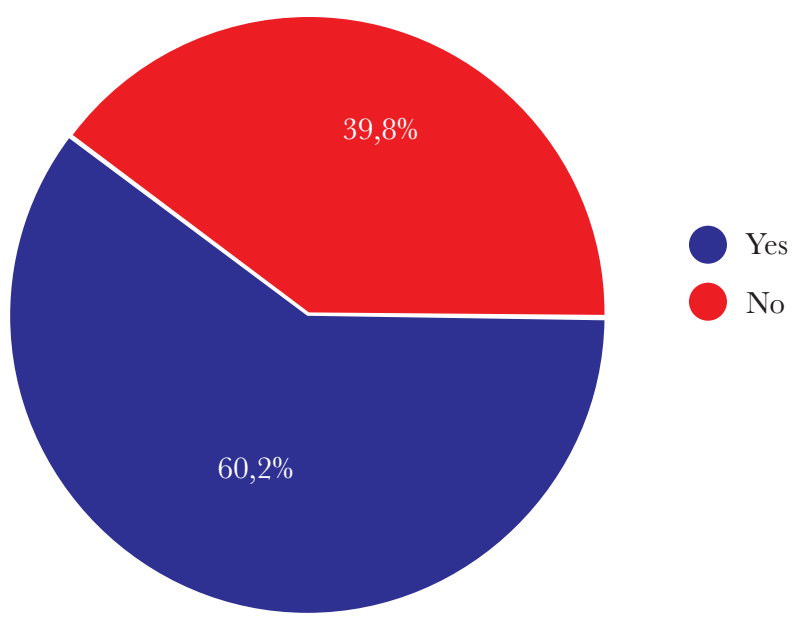

Figure 3. Percentage representation in relation to question number 1 .

Organic agriculture is defined as an alternative production that relates environmental, social, and economic aims (Romero Valenzuela et al., 2016). At the same time, it is gradually combined with the widespread acceptance of sustainable development as a concept that fully satisfies the needs of current generations without compromising the future generations' sufficiency to compensate for their own needs (Brundtland, 1987).

To know if population had consumed certified organic food, we asked the following question: Have you ever consumed certified organic food? The results showed that $42.2 \%$ considered that they had consumed certified organic food at some time, while $41 \%$ of the population interviewed stated that they had not consumed it, and a lower percentage 
(16.8\%) stated that they had possibly consumed it but did not realize it, since most of the times when purchasing food they do not check the labeling. These results suggest that the proportion of people who have consumed this type of food is similar to those who have not consumed it; however, the percentage of people who have consumed it could be higher if we take into account that there is a percentage who are not aware of whether they have consumed it or not (Figure 4).

The consumption of organic food is related to health care. If it is affordable to consumers, they will prefer to pay a higher price to ensure that their food is free of pesticides or toxic agents. However, the product availability in different regions of the country is a decisive consumption factor of this type of food. Although its consumption is reduced when compared against other types of food. In the market, organic food has great potential due to the nutritional benefits it can generate to the organism as well as the environmental protection.

Considering all the above, we searched if the population had enough information to purchase these foods, so we asked if they knew any establishment or online store where certified organic foods could be purchased. The results showed that $53 \%$ of the interviewed population knows the places where this type of products can be purchased, while $47 \%$ do not know where to buy them. These results showed that half of the population knows where to go while the other half does not (Figure 5).

Manufacturers and companies should publicize their products and their distribution points so the interested population could acquire them easily. Likewise, organic food demand in establishments such as supermarkets impacts the cost, which makes it harder to find in any establishment. Besides the price, the feasibility and guarantee of the product is another influential factor at the moment of purchase; therefore, the family income is also a determinant for buying this type of food, so it is not only a matter of knowledge. Generally, the population is now more concerned about the environment, so it is becoming more important to emphasize areas such as green publicity. Society's interest in organic food is increasing due to people's concern about caring for greenery

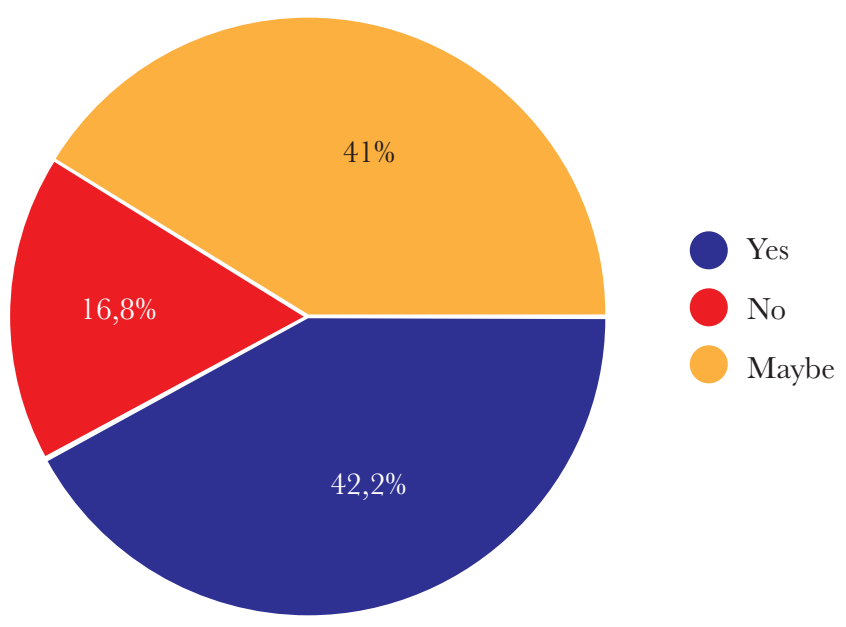

Figure 4. Percentage representation in relation to question number 2. 


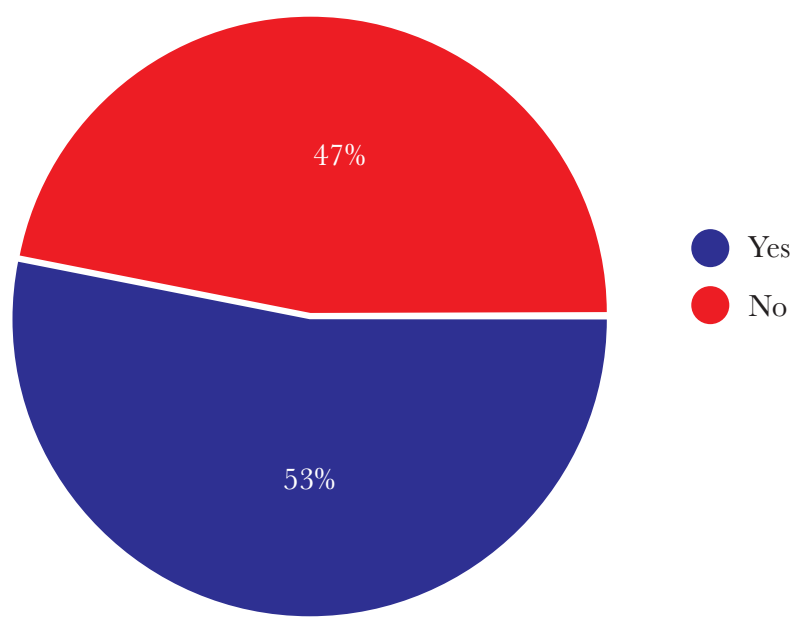

Figure 5. Percentage representation in relation to question number 3.

and having a deeper understanding of the damage caused to nature by the misuse of resources provided to industries and society itself (Mc Donnell, Reginald, 2008).

To deepen the knowledge about the establishments where this type of food could be purchased, it was asked: "What is the establishment or online store where you could buy certified organic food?" For this, 28.9\% of the participants answered: "I do not know any establishment" and a similar percentage answered in "supermarkets" (27.7\%). One-fifth of the population thought that these could be purchased through the "Internet (Amazon, Mercado Libre, etc.)" and a smaller percentage of $13.3 \%$ stated that certified organic food can be purchased in local markets, which was questionable since there are few certified organic food markets, and in the municipalities in which the survey was conducted, there is no record of the existence of the certification of these, although they may be organic food, by not having an assigned certification it cannot be said that it is a certified organic food; finally the remaining 9.6\% answered that they could purchase these foods in other types of places (Figure 6).

To find out if the interviewed population had an idea of organic food's economic cost, we asked: "Do you consider that all certified organic foods are more expensive, which might influence your decision to consume it?" The results achieved showed that most of the population (63.9\%) considers that the prices of certified organic foods are higher when compared to non-certified ones. These foods are more expensive than those commonly purchased, due to several reasons: 1.- The production processes require labor for each product, 2.- Since they are batches of small quantities, the cost of their mobilization increases 3.- Sale is limited since the demand for them is low. The rest of the people who answered the survey were divided into $27.7 \%$ who did not know if the prices of certified organic foods were higher or not, while the remaining $8.4 \%$ thought that they did not have higher prices compared to those they consume more frequently. However, two possible reasons to explain the answer to question 5 is that certified organic foods were probably not purchased by them, or they simply did not consider them to be higher priced (Figure 7). 


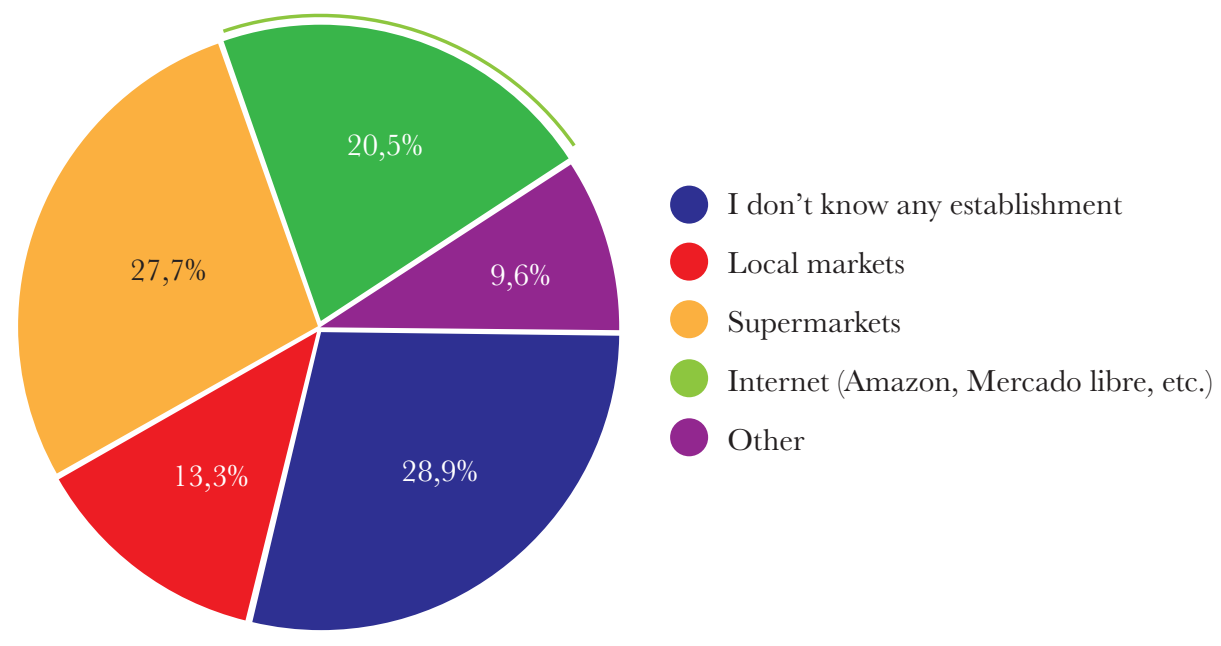

Figure 6. Percentage representation in relation to question number 7.

To determine whether the interviewed population has an idea about the impact that certified organic foods can cause to human health, the following question was asked: Do you consider that the consumption of certified organic foods is beneficial or detrimental to your health? The results were divided into two main groups: on the one hand, half of the population, $49.4 \%$, indicated that the frequency of consumption of this type of food does not harm health. However, 50.6\% of the population considered that they can have an adverse or detrimental effect on health, depending on the consumption frequency. To clarify this possibility, it can be exemplified with the excessive consumption of some organic fruits that could affect health because they may have a higher index of total sugars compared to the foods commonly consumed (Kowska et al., 2012), impacting the consumption of a high-fructose diet, which reduces circulating concentrations of insulin, leptin and decreases postprandial suppression of ghrelin, which might promote increased caloric intake and therefore, leading to undesirable weight gain and obesity (Schaefer et al., 2009). One of the major disadvantages of these foods is that since they have a

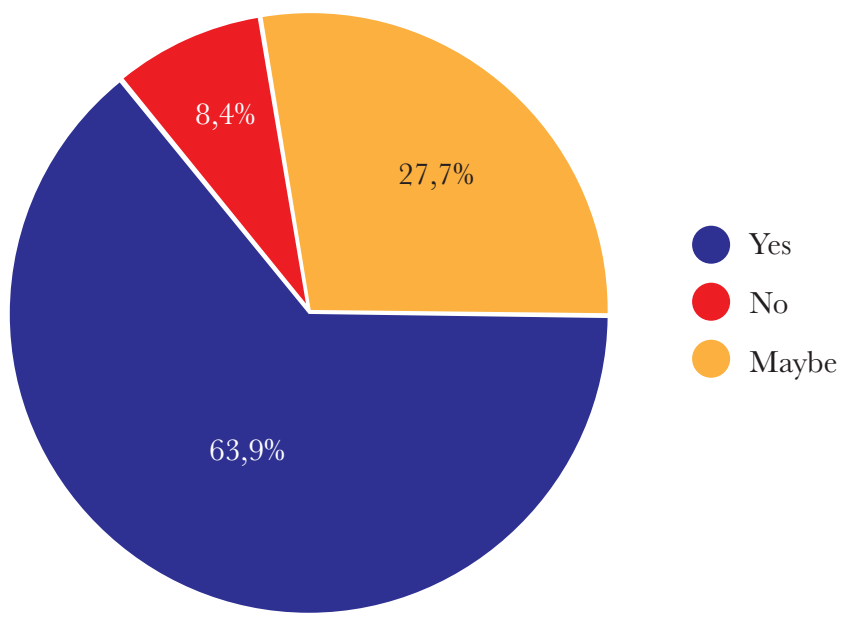

Figure 7. Percentage representation in relation to question number 5. 
shorter shelf life, it could be consumed after the recommended consumption dates and, consequently, could lead to infections and intoxications (Figure 8).

Finally, to find out if the population knows about the impact that consuming certified organic food can have on the environment, we proceeded to ask if they consider that certified organic food has a positive or negative impact on the environment? The results obtained suggest that the majority of the population interviewed (59\%) considered that the consumption of these foods is "positive for the environment", while $39.8 \%$ did not know if the consumption of these foods has a positive impact on the environment, and finally only $1.2 \%$ stated that certified organic foods have a "negative impact on the environment".

The positive environmental impact that certified organic food generates is largely since agrochemicals are not used during agriculture, thus avoiding contamination and degradation of natural resources. In this way, competent and effective products are obtained, which quality is due to the non-use of fertilizers, pesticides as well as pharmaceuticals that are usually used in common food agriculture. Some of the agricultural methods for harvesting these foods seek an ecological balance between planting and profit, since the ecosystem is the primary production input (Fliessbach et al., 2001). However, despite having many points for the positive impact on the environment, it should be taken into account that most of the packaging of these foods are presented in cans, non-biodegradable plastic bags, unicel, plastic nets, polyethylene containers, among some others that continue to have a negative impact on environmental pollution, not only in the soil itself, but also in the seas, rivers, lakes and lagoons as well as in the air and in effect to the very health of living beings, since some plastics, being non-biodegradable, become non-biocompatible and therefore when integrated into organisms become toxins that are harmful to health (Chemical Society Journal, 2011). The correct management of food packaging waste should be made known to the population, to improve the quality of the environment, and when they are properly selected, they can be recycled in a much more effective and efficient way (Marsh K., 2007) (Figure 9).

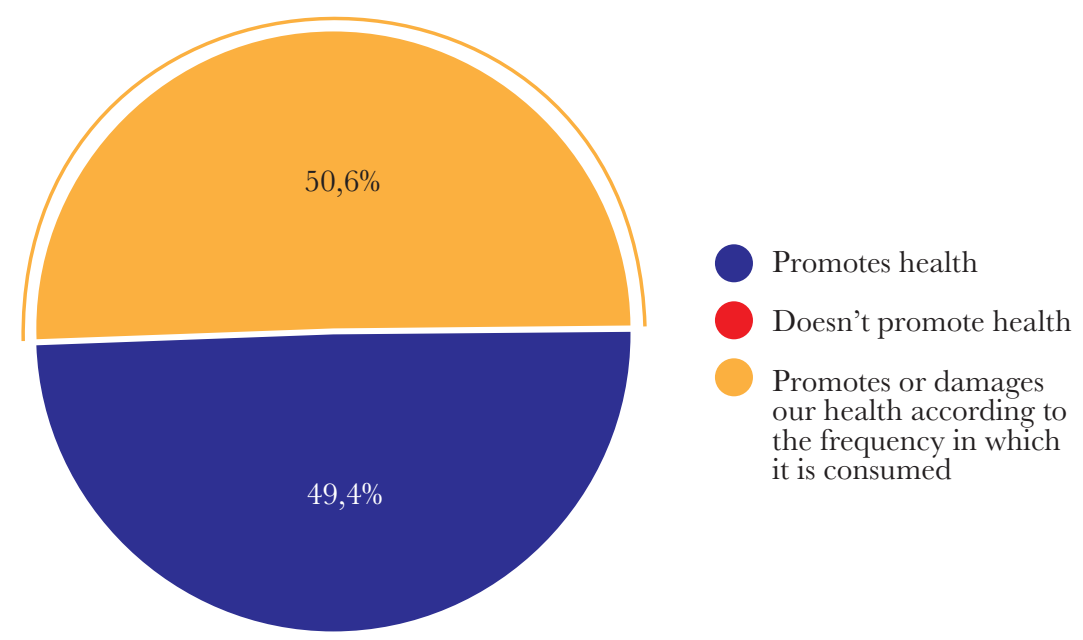

Figure 8. Percentage representation in relation to question number 6. 


\section{GONGLUSIONS}

Certified organic foods provide a certain guarantee to their consumers, the non-use of synthetic agrochemicals, as well as transgenic materials in their production process and techniques. Animal products ensure that aspects related to animal welfare have been respected. From the sample studied, 35 people have consumed certified organic food, however, because its price is higher than a common food, they are not affordable and in fact are rarely consumed.

Another factor is the limited availability in Mexico of organic agriculture and the accepted certifications required to guarantee the product, because of the above mentioned, the places where these products can be acquired are very scarce or totally unknown, since 24 of the people who answered the survey did not know the places where these foods are acquired. In addition, the health benefit favor or harm according to their frequent consumption; it should be clarified that not being a certified organic food will not have negative effects on the body when its consumption is exceeded, likewise it is important to know that food packaging is essential and indispensable, as it protects the food between the transformation process and how it reaches the consumer. Food packaging must be disposed in an environmentally responsible manner, so it is necessary to raise awareness when purchasing a product. Different forms of packaging should also be innovated to use less cans, unicells, bags and polyethylene.

\section{REFERENGES}

Brundtland, G. H. (1987). Report of the World Commission on Environment and Development: Our Common Future. United Nations. Disponible en: http://www.un-documents.net/our-commonfuture.pdf

Camacho, E., Melissa y Vega-Baudrit, J., Campos-Gallo, A. (2011). Uso de nanomateriales en polímeros para la obtención de bioempaques en aplicaciones alimentarias. Revista de la Sociedad Quimica del Perú. 77(4): 292-306.

Cooper, J., Leifert, C., Niggli, U. (2007). Handbook of Organic Food Safety and Quality. Research Institute of Organic Agricultura (FiBL), Switzerland.

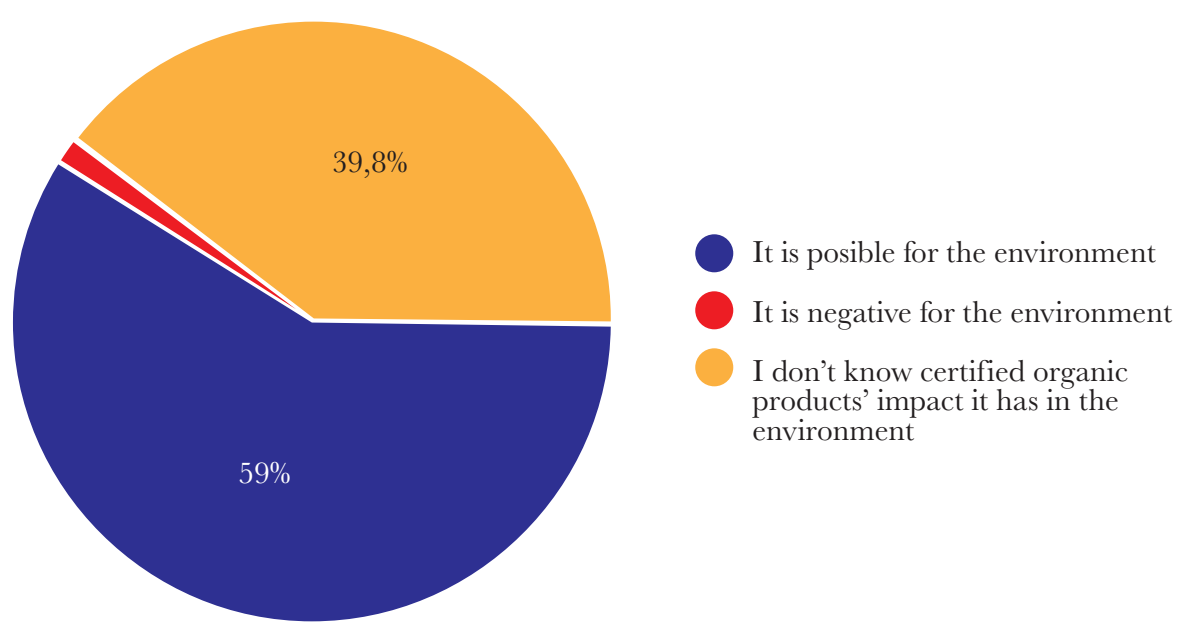

Figure 9. Percentage representation in relation to question number 7. 
Díaz-Víquez, A., Pérez-Hernández, A., Hernández-Ávila, J. (2015). Caracterización del consumidor de productos orgánicos en la ciudad de Tóluca, México. Revista Mexicana de Agronegocios. 36: 1178-1 187.

Fließbach, A., Oberholzer, H.-R., Gunst, L., Mäder, P. (2007). Soil organic matter and biological soil quality indicators after 21 years of organic and conventional farming. Agriculture, Ecosystems and Environment. 118:273-284. Doi: 10.1016/j.agee.2006.05.022

Food and Agriculture organization, FAO. (2007) Organic Agriculture-What are certified organic products? Disponible en: http://www.fao.org/organicag/oa-faq/oa-faq2/en/

Gentile, N., Rodríguez, E. (2006). El consumo de alimentos orgánicos: Aplicación de un modelo logit multinomial en la elección del canal de compra. In Rodríguez, Elsa Mirta M., (Ed.), El mercado de alimentos orgánicos. Producción y consumo de los principales productos argentinos (pp. 59-78) Universidad Nacional de Mar del Plata, Facultad de Ciencias Económicas y Sociales, Centro de Documentación. Disponible en: http://nulan.mdp.edu.ar/1065/1/gentile.rodriguez.2006.pdf

Gobierno de México (2018) Alimentos Orgánicos. Disponible en: https://www.gob.mx/profeco/documentos/ alimentos-organicos.

Gómez, M.A., Gómez, L. M., R. Schwentesius. (1999). Desafíos de la agricultura orgánica, comercialización y certificación. México, UACH y CIESTAM, Editorial Mundi-Prensa.

Gómez, M. A., Gómez, L., Schwentesius, R. (2002). Dinámica del mercado internacional de productos orgánicos y las perspectivas para México. Revista. Momento Económico. 120: 54-68.

Kenneth, M., Bugusu, B. (2007). Food Packaging -Roles, materials, and environmental issues. Journal of Food Science. 72 (3): 39-55. Doi: 10.1111/j.1750-3841.2007.00301.x

Rembiałkowska, E., Kazimierczak, R., Średnicka, D., Bieńko, K., Bielska, M. (2008). Different aspects of Organic and Conventional Food Consumers, Lifestyle. New Medicine. 1,16-19

Romero Valenzuela, D. M., Camarena Gómez, B. O., Camarena Gómez, D. M. J. (2016). Oferta de productos hortofrutícolas orgánicos en Hermosillo, Sonora. Vertice Universitario 69, 2-9.

SAGARPA Servicios de Información Agroalimentaria y Pesquera (SIAP). (2016). Atlas Agroalimentario. Disponible en: https://www.gob.mx/siap/articulos/atlas-agroalimentario-2016-siap-presenta-losexitos-del-campo-mexicano

Willer, Helga and Lernoud, J. (2019). The World of Organic Agriculture: Statistics and Emerging Trends 2019. ISBN PDF version 978-3-03736-119 